\title{
Saliva profiles in children with congenital heart disease ${ }^{*}$
}

\section{Purpose}

The low salivary $\mathrm{pH}$ and buffering capacity are caused by using heart failure medications. For this reason oral health should be supported in cardiac patients, it is necessary that they attend dental clinics for regular follow up. The aim of this study is to evaluate the relationship between the salivary oxidative stress markers and salivary $\mathrm{pH}$, salivary buffering capacity, salivary flow rate and dental caries of children with congenital heart disease (CHD).

\section{Material and Methods}

This cross sectional study was carried out with $42 \mathrm{CHD}$ and 42 healthy children. The participants' gender, age, general health and medications, and caries scores (dfs/ DMFS) were written down, then their unstimulated saliva samples were collected. These specimens were evaluated in terms of the salivary secretion rate, salivary buffering capacity, $\mathrm{pH}$, protein levels, superoxide dismutase (SOD), ferric reducing antioxidant power (FRAP), the thiobarbituric acid reactive substances (TBARS), protein carbonyl, protein thiols, total sialic acid.

\section{Results}

Both groups showed caries at similar levels. The salivary $\mathrm{pH}$ and buffering capacity were significantly less in the children with CHD than in the controls. The levels of TBARS and protein carbonyl were significantly higher in the children with CHD than in the controls. There was not any significant difference relating to the mean salivary secretion rate, protein levels, SOD, FRAP, protein thiols and total sialic acid.

\section{Conclusion}

The elevated TBARS and protein carbonyl levels in the patients with CHD were observed as an indicator of the free radical damage leading to oxidative stress.

Keywords: Saliva composition; antioxidant activity; caries risk factors; congenital cardiac diseases; pedodontics

\section{Introduction}

Congenital heart disease (CHD) is the one of the most common congenital anomalies in children, approximately 8-10 of the 1000 children around the world are born with CHD $(1,2)$. Oral health problems are known to be common in children with severe heart disease, especially in the early ages, and accordingly an increasing number of patients require careful dental care $(3,4)$. This group of children often required heart failure medications. It is well known that these medications change the saliva composition and biochemical properties in saliva such as levels of antioxidant and free radicals, but it is unknown whether there is a correlation between these biochemical properties and oral health problems (3).

With a better understanding of specific concentrations of salivary composition and its main components, both immunological and biochemical, different systemic and/or local pathologies can be located and assessed through the analysis of salivary composition and the flow rate (5).

\author{
Mine Koruyucu ${ }^{1}$ D, \\ Sule Batu² ${ }^{(D}$, \\ Merve Bayram ${ }^{\text {iD, }}$ \\ Ezel Uslu ${ }^{4}$ iD, \\ Yegane Güven² ${ }^{(1)}$, \\ Figen Seymen ${ }^{1}$ (i)
}

*The study was registered at ClinicalTrials.gov (NCT03457974).

Presented at: $11^{\text {th }}$ Congress of the European Academy of Paediatric Dentistry 24-27 th May 2012 Strasbourg, France.

ORCID IDs of the authors: M.K.0000-0002-2077-5095; S.B. 0000-0002-6834-477X; M.B. 0000-0002-8440-367X; E.U. 0000-0003-3925-0851; Y.G. 0000-0003-4718-927X; F.S. 0000-0001-7010-2035

${ }^{1}$ Istanbul University, Faculty of Dentistry, Department of Pedodontics, Istanbul, Turkey

${ }^{2}$ Istanbul University, Faculty of Dentistry, Department of Biochemistry, Istanbul, Turkey

${ }^{3}$ Istanbul Medipol University, Faculty of Dentistry, Department of Pedodontics, Istanbul, Turkey

${ }^{4}$ Istanbul Cerrahpasa University, Faculty of Medicine, Department of Biochemistry, Istanbul, Turkey

Corresponding Author: Mine Koruyucu E-mail: mine.yildirim@istanbul.edu.tr

Received: 11 December, 2018 Revised: 24 January, 2019 Accepted: 13 February, 2019 DOI: 10.26650/eor.20200087 
A number of researchers have studied oral fluids to assess the aspects of systemic diseases, including CHD. Various serum biomarkers in oral fluids are known to be associated with inflammation, atherosclerosis, and myocardial damage $(6,7)$.

Various researches have found evidence that a lot of cardiovascular diseases such as hypertension, type II diabetes, hypercholesterolaemia, atherosclerosis, and heart failure are influenced by oxidative stress in their pathogenesis. However, it is not clear that cardivascuar disease pathogenesis is primarily caused by oxidative stress $(8,9)$. The researches have found a close relationship between the salivary biochemical and antioxidants systems in several pathological conditions and salivary components (5).

As formerly reported that the components in saliva can protect the oral cavity against the negative effects of endogenous and exogenous free radical damage as there are many antioxidant mechanisms in saliva (10).

One of the most important functions of antioxidants is the control of the oral bacteria that forms dental plaque, leading to an imbalance in ecology which causes dental caries and chronic inflammatory periodontal diseases. Salivary antioxidant defense systems and its relation to oral diseases have not been studied enough and there have been no studies conducted on total antioxidant status of saliva and whether this has any affect on caries protection in children (11).

In this study, we evaluated salivary oxidative stress status of children with CHD We included caries scores, gender, age, salivary flow rate, salivary $\mathrm{pH}$, salivary buffering capacity and drug intake such as angiotensin-converting enzyme (ACE) inhibitors and tried to conclude a direct relationship between them. The null hypothesis is that the use of drugs such as angiotensin converting enzyme (ACE) inhibitors in children with CHD may affect salivary flow rate, $\mathrm{pH}$, buffering capacity, salivary oxidative stress status and dental caries. If such relationships exist, they might be employed to patient caries - prevention treatment.

\section{Material and Methods}

The study was approved by the Ethics Committee of the Istanbul University, Medical Faculty (No:2010/1109-378) and was carried out in agreement with the Declaration of Helsinki principles. The study was registered at ClinicalTrials. gov (NCT03457974). This cross-sectional study was carried out 42 CHD and 42 healthy children who applied to Istanbul University Faculty of Dentistry. Patients in the high caries risk group were included in the study who were diagnosed in the cardiology department. Before participation to the study, the parents gave their informed consents in writing.

The children with congenital heart disease, aged 3-12 years who agree to give saliva were included in the study group. The children with no systemic disease, aged 3-12 years who agree to give saliva were included in the control group.

Gender, age, general health and medications, dfs/DMFS scores (total $s=$ surface of $d=$ decayed, $m=$ missing, $f=$ filled teeth) were recorded. Unstimulated saliva was collected.

In the presented work, the protein carbonyl and protein thiol-markers of the oxidative damage to the proteins and the thiobarbituric acid reactive substances (TBARS)- markers of lipoperoxidation were analysed. The antioxidant activities were evaluated by ferric reducing antioxidant power (FRAP) and superoxide dismutase (SOD) assays. The total protein concentration, sialic acid content and flow rate, $\mathrm{pH}$ and buffering capacity of the saliva were also assessed.

The saliva samples were collected in morning hours and at least 2 hours after the last food or drink. Prior to saliva collection mouths were rinsed out with distilled water and unstimulated whole saliva was collected for $5 \mathrm{~min}$ with the subject leaning forward and spitting saliva into a graded sampling tube. The flow rates were evaluated visually from graded test tubes (as $\mathrm{ml} / \mathrm{min}$ ). The Ericsson's method was used to measure the buffering capacity (12).

After the samples were collected, they were centrifuged instantly (4000 rpm for $10 \mathrm{~min}$ at $4^{\circ} \mathrm{C}$ ), and the upper parts were drawn and stored in small aliquots at $-80^{\circ} \mathrm{C}$ until analyzed.

Bovine serum albumin was used as standard in bicinchoninic acid (BCA) method to determine the salivary total protein concentrations (13). In short, $10 \mu \mathrm{L}$ of saliva was mixed with the $200 \mu \mathrm{L}$ of BCA working reagent, incubated $30 \mathrm{~min}$ at $37^{\circ} \mathrm{C}$, and measured at $562 \mathrm{~nm}$. The results were specified in $\mathrm{mg} / \mathrm{mL}$.

The measurement of salivary SOD activity was done with a modified method of Sun et al.(14). A superoxide generator, the xanthine oxidase was used in the inhibition of the nitroblue tetrazolium (NBT) reduction in this analysis. There are $40 \mathrm{ml}$ of $0.3 \mathrm{mmol} / \mathrm{I}$ xanthine solution, $20 \mathrm{ml}$ of $0.6 \mathrm{mmol} / \mathrm{I}$ EDTA solution, $12 \mathrm{ml}$ of $400 \mathrm{mmol} / / \mathrm{Na}_{2} \mathrm{CO}_{3}$, and $6 \mathrm{ml}$ of bovine serum in the reaction mixture. The final concentration of xanthine oxidase was $167 \mathrm{U} / \mathrm{l}$. The SOD enzyme inhibited this reaction by scavenging the superoxide anion. There was a level of enyzyme that was able to inhibit the optical density at $560 \mathrm{~nm}$ of NBT reduction by $50 \%$ in 1 minute under the assay conditions, which defined the unit of SOD enzyme activity. The results were specified as $\mathrm{U} / \mathrm{ml}$ of the saliva.

The measurement of salivary FRAP levels were done as stated by Benzie and Strain (15).

Briefly, in this test, antioxidant activity occured following the exposion of the medium to $\mathrm{Fe}^{3+}$ as the antioxidants in it begin to produce $\mathrm{Fe}^{2+}$ afterwards.

Shortly before use, $300 \mathrm{mM}$ acetate buffer (pH 3.6), 10mM 2,4,6-tripyridyl-s-triazine (TPTZ) solution and $20 \mathrm{mM} \mathrm{Fe-}$ $\mathrm{Cl}_{3} \cdot 6 \mathrm{H}_{2} \mathrm{O}$ were mixed in a 10:1:1 ratio to become the working FRAP agent. Then this mixtuare was heated to $37^{\circ} \mathrm{C} .10 \mathrm{mM}$ TPTZ was added to $40 \mathrm{mM} \mathrm{HCl}$ to get the TPTZ solution. The reagent that was preaped and heated to $37^{\circ} \mathrm{C}$ was mixed with ten $\mu \mathrm{L}$ of $\mathrm{H}_{2} \mathrm{O}$-diluted sample afterwards. Blue color was observed when $\mathrm{Fe}^{2+}$ and TPTZ became a complex. $593 \mathrm{~nm}$ was the absorption rate of this complex. Ascorbic acid was used to prepare the FRAP standards $(100-1000 \mu \mathrm{M})$, which was the same in all samples. Ascorbic acid was used as standard, and the concentration of FRAP was expressed in $\mu \mathrm{mol} / \mathrm{L}$.

The oxidation of the polyunsaturated fatty acids creates MDA (Malondialdehyde) as the end product. The extent of lipid peroxidation's established measure is MDA's concentration in the medium. In this test, spectrophotometrically determined complex was achieved through the reaction of MDA with the thiobarbituric acid (TBA). The amount of TBARS produced was used to assess the lipid peroxidation in samples (16).

In short, 15\% w/v trichloroacetic acid, 0.375\% w/v TBA, and $0.25 \mathrm{~N}$ hydrochloric acid was mixed as a stock solution, whose two volumes were mixed with one volüme of the sample all through. The mixture was incubated for $30 \mathrm{~min}$ in 
a boiling water bath. When the mixture cooled off, centrifugation was applied at $1000 \mathrm{xg}$ for $10 \mathrm{~min}$ to remove the flocculent precipitate. The absorption of the supernatant was recorded at $535 \mathrm{~nm}$. The TBARS concentration was calculated using $1.56 \times 10^{5} \mathrm{M}^{-1} \mathrm{~cm}^{-1}$ as molar extinction coefficient. The results were expressed in $\mathrm{nmol} / \mathrm{ml}$.

Spectrophotometric measurement of the saliva protein carbonyl (PCO) levels was done by using the method of Reznick et al. Chromophoric dinitrophenylhydrazones can be generated when the PCO groups react with 2,4-dinitrophenylhydrazine (DNPH) (17). After the dissolvement of $\mathrm{DNPH}$ in $\mathrm{HCl}$ and its reaction, precipition of the proteins with trichloroacetic acid (with an equal volume of $20 \%(\mathrm{w} / \mathrm{v})$ ) occured. $4 \mathrm{ml}$ of an ethanol/ethyl acetate mixture (1:1) was used to wash it three times and afterwards it centifugared at $6000 \times \mathrm{g}$ for $5 \mathrm{~min}$. In the end, $6 \mathrm{M}$ guanidine- $\mathrm{HCl}$ solution was used for dissolution of the precipititates, and measurement of the absorbances at $360 \mathrm{~nm}$ was observed. The molar extinction coefficient of DNPH, $\varepsilon=2.2 \times 10^{4} \mathrm{M}^{-1} \mathrm{~cm}^{-1}$ was used for the determination of the carbonyl content. The results were specified in $\mu \mathrm{mol} / \mathrm{L}$.

A modified Ellman's method was used for measurement of the salivary protein thiol levels (18). The complex of 5, 5'-dithiobis-2-nitrobenzoic acid (DTNB), also known as Ellman's reagent, andthiol compounds (-SH groups) observed as yellow because of the reaction with a maximum peak at $412 \mathrm{~nm}$.

In short, the mixture of, $0.2 \mathrm{ml}$ of saliva, phosphate buffer (pH 8.0), $40 \mu \mathrm{l}$ of $10 \mathrm{mM}$ DTNB and $3.16 \mathrm{ml}$ of methanol was incubated for $10 \mathrm{~min}$, and the absorbance was measured at $412 \mathrm{~nm}$ against appropriate blanks. The protein thiol content was calculated by using $13.6 \times 10^{3} \mathrm{~cm}^{-1} \mathrm{M}^{-1}$ as the molar extinction coefficient (19). The results were specified in $\mu \mathrm{mol} / \mathrm{L}$.

A modified method which gave advanced sensitivity and high reproducibility to sialic acid (SA) were proposed by Tram et al. (1997) and this TBA method was used to determine the SA concentrations (Aminoff, 1961) t The saliva samples were incubated with $0.1 \mathrm{~N} \mathrm{H}_{2} \mathrm{SO}_{4}$ at $80^{\circ} \mathrm{C}$ for 60 minutes, and the total $\mathrm{SA}$ were determined in hydrolysate by measuring the absorbance $549 \mathrm{~nm}$. The calculation of the sialic acid content in the sample was performed by a comparison with a standard curve prepared with $\mathrm{N}$-acetylneuraminic acid (20-22).

\section{Statistical analysis}

Statistical analysis was done with SPSS (Statistical Package for Social Sciences) for Windows 15.0 program. Kolmogrov-Smirnov test was used for the normal distribution suitability of the parameters. As well as the descriptive statistical methods (Mean, Standard Deviation, frequency), Oneway Anova test, Kruskal Wallis test, Student T test, Mann Whitney U test, Chi-square test, Pearson correlation and Spearman's rho correlation ayalsis were used to examine the relationships between variables. The significance was assessed at $p<0.05$ level.

\section{Results}

The study population comprised of 84 patients ( 42 cardiac-42 healthy), 28 (33.3\%) female, 56 (66.7\%) male, and 3-to 12-year-old (mean age 7.19 \pm 2.37 ) children. Gender and ages were selected same for study and control groups. There was 14 female and 28 male in both groups. In both groups there were 17 children between the ages of 3-6 and 25 children between the ages of 7-12 years. The significant difference

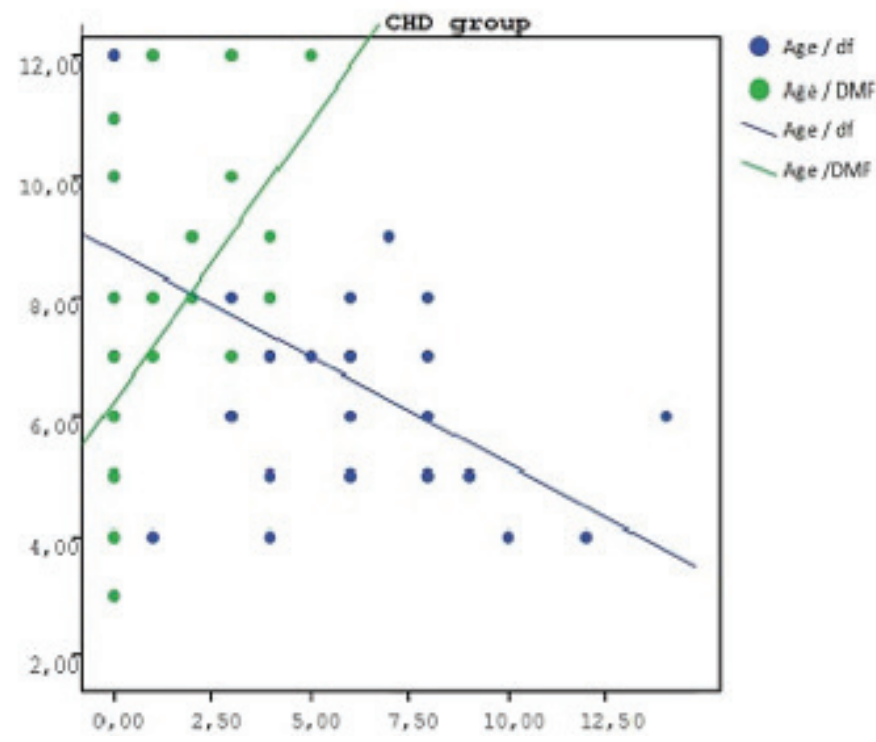

Figure 1. Correlation between age and caries scores.

\begin{tabular}{|c|c|c|c|}
\hline & & & \\
\hline & Study group (CHD) & Control group & $p$ value \\
\hline Dfs & $4.40 \pm 3.49$ & $5.00 \pm 2.94$ & 0.274 \\
\hline DMFS & $1.02 \pm 1.53$ & $1.14 \pm 1.63$ & 0.744 \\
\hline Salivary flow secretion rate $(\mathrm{ml} / \mathrm{min})$ & $0.42 \pm 0.33$ & $0.40 \pm 0.29$ & 0.683 \\
\hline Salivary buffering capacity & $4.40 \pm 0.63$ & $4.84 \pm 0.55$ & $0.001 * *$ \\
\hline Salivary pH & $6.63 \pm 0.67$ & $6.85 \pm 0.41$ & $0.041 *$ \\
\hline Protein levels (mg/ml) & $0.16 \pm 0.07$ & $0.14 \pm 0.06$ & 0.162 \\
\hline +SOD (U/ml) & $1.50 \pm 0.58$ & $1.24 \pm 0.58$ & 0.055 \\
\hline +FRAP ( $\mu \mathrm{mol} / \mathrm{L})$ & $627.26 \pm 168.12$ & $571.05 \pm 221.39$ & 0.221 \\
\hline +TBARS (nmol/ml) & $0.70 \pm 0.19$ & $0.55 \pm 0.15$ & $0.001 * *$ \\
\hline +Protein carbonyl ( $\mu \mathrm{mol} / \mathrm{L})$ & $53.06 \pm 18.30$ & $19.93 \pm 16.23$ & $0.001 * *$ \\
\hline +Protein thiols $(\mu \mathrm{mol} / \mathrm{L})$ & $56.70 \pm 25.96$ & $65.23 \pm 51.38$ & 0.390 \\
\hline +Total sialic acid (mg SA/dL) & $7.43 \pm 2.41$ & $6.14 \pm 4.07$ & 0.099 \\
\hline
\end{tabular}


Table 2. SOD, FRAP, protein thiols, total sialic acid, TBARS ve protein carbonyl relationship with age in the CHD group

\begin{tabular}{lcc}
\multirow{2}{*}{ CHD group } & \multicolumn{2}{c}{ Age } \\
\cline { 2 - 3 } & $\boldsymbol{r}$ & $\boldsymbol{p}$ \\
\hline SOD $(\mathrm{U} / \mathrm{ml})$ & -0.251 & $\mathbf{0 . 1 0 9}$ \\
\hline FRAP $(\boldsymbol{\mu m o l} / \mathrm{L})$ & 0.055 & $\mathbf{0 . 7 4 6}$ \\
\hline Protein thiols $(\boldsymbol{\mu m o l} / \mathrm{L})$ & 0.108 & $\mathbf{0 . 5 4 4}$ \\
\hline Total Sialic Acid $(\mathrm{mg} \mathrm{SA} / \mathrm{dL})$ & -0.014 & $\mathbf{0 . 9 3 1}$ \\
\hline TBARS $(\mathrm{nmol} / \mathrm{ml})$ & 0.021 & $\mathbf{0 . 8 9 4}$ \\
\hline Protein Carbonyl $(\boldsymbol{\mu m o ~} / \mathrm{L})$ & -0.109 & $\mathbf{0 . 4 9 2}$ \\
\hline Pearson correlation analyses, $\mathrm{p}<0.05$ & & \\
\hline
\end{tabular}

was not found between the groups according to the ages and gender $(p>0.05)$.

The mean dfs and DMFS scores, were found respectively $4.40 \pm 3.49,1.02 \pm 1.53$ for the cardiac group; $5.00 \pm 2.94$, $1.14 \pm 1.63$ for the control group. According to the groups statistically significant differences were not found between scores ( $p>0.05$ ) (Table 1). In the CHD group, statistically sig- nificant negative relationship was found between age and dfs scores $(r=-0.500, p<0.01)$. Also statistically significant positive relationship was found between age and DMFS $(r=0.701, p<0.01)$ (Figure 1).

Statistically significant differences were not found between the mean salivary flow secretion rate $(p=0.683$, $\mathrm{p}>0.05$ ) (Table 1).

The salivary buffering capacity $(\mathrm{p}=0.001)$ and salivary $\mathrm{pH}$ $(p=0.041)$ were significantly less in the CHD than in the controls $(p<0.05, p<0.01)$ (Table 1$)$.

The statistically significant difference was not found between the mean protein levels ( $p=0.162$, $(p>0.05)$ (Table 1).

The statistically significant difference was not found between the mean SOD $(p=0.055)$ and the FRAP $(p=0.221)$ values ( $p>0.05$ ) (Table 1). However, the SOD values of the children with CHD were found to be higher than the control group.

The levels of TBARS and protein carbonyl $(p=0.001)$ were significantly higher in the CHD than in the controls $(p \leq 0.01)$ (Table 1).

The statistically significant difference was not found between the mean protein thiols $(p=0.390)$ and the total sialic acid $(p=0.099)(p>0.05)$ (Table 1$)$.

Table 3. Evaluation of salivary secretion rate, $\mathrm{pH}$ and salivary buffering capacity according to age groups

\begin{tabular}{|c|c|c|c|}
\hline & $\begin{array}{c}\text { CHD } \\
\text { mean } \pm \text { SD (median) }\end{array}$ & $\begin{array}{c}\text { Control } \\
\text { mean } \pm S D \text { (median) }\end{array}$ & $p$ \\
\hline \multicolumn{4}{|l|}{ Age 3-6 } \\
\hline Salivary secretion rate (ml/min) & $0.34 \pm 0.32(0.22)$ & $0.35 \pm 0.34(0.25)$ & 0.966 \\
\hline pH & $6.55 \pm 0.68(6)$ & $6.73 \pm 0.45(7)$ & 0.196 \\
\hline Salivary buffering capacity & $4.08 \pm 1,59(4.5)$ & $4.12 \pm 1.88(4.5)$ & 0.478 \\
\hline SOD (U/ml) & $1.38 \pm 0.78$ & $0.97 \pm 0.64$ & 0.084 \\
\hline TBARS (nmol/ml) & $0.59 \pm 0.31$ & $0.47 \pm 0.19$ & 0.157 \\
\hline \multicolumn{4}{|l|}{ Age 7-12 } \\
\hline Salivary secretion rate (ml/min) & $0.47 \pm 0.36(0.4)$ & $0.42 \pm 0.24(0.38)$ & 0.950 \\
\hline pH & $6.63 \pm 0.77(7)$ & $6.92 \pm 0.38(7)$ & 0.082 \\
\hline Salivary buffering capacity & $4.13 \pm 0.96(4.5)$ & $4.94 \pm 0.53(5)$ & $0.001 * *$ \\
\hline SOD (U/ml) & $1.41 \pm 0.59$ & $1.27 \pm 0.61$ & 0.428 \\
\hline TBARS (nmol/ml) & $0.71 \pm 0.19$ & $0.55 \pm 0.18$ & $0.004 * *$ \\
\hline Student $\mathrm{t}$ test, Mann Whitney $\mathrm{U}$ test, ${ }^{* *} \mathrm{p}<0.0$ & & & \\
\hline
\end{tabular}

Table 4. Evaluation of SOD, FRAP, protein thiol, total sialic acid, TBARS, protein carbonyl, dfs and DMFS according to ACE inhibitor usage in the CHD group

\begin{tabular}{|c|c|c|c|}
\hline \multirow[b]{2}{*}{ CHD group } & \multicolumn{2}{|c|}{ Medication } & \multirow[b]{2}{*}{${ }^{+} \boldsymbol{p}$} \\
\hline & $\begin{array}{c}\text { usage+ } \\
\text { Mean } \pm \text { SD }\end{array}$ & $\begin{array}{c}\text { usage - } \\
\text { Mean } \pm S D\end{array}$ & \\
\hline SOD (U/ml) & $1.41 \pm 0.64$ & $1.53 \pm 0.56$ & 0.545 \\
\hline FRAP ( $\mu \mathrm{mol} / \mathrm{L})$ & $593.25 \pm 169.72$ & $638.19 \pm 169.25$ & 0.493 \\
\hline Protein thiol ( $\mu \mathrm{mol} / \mathrm{L})$ & $59.02 \pm 24.85$ & $55.98 \pm 26.74$ & 0.778 \\
\hline Total Sialic Acid (mg SA/dL) & $8.51 \pm 3.24$ & $6.99 \pm 1.89$ & 0.066 \\
\hline TBARS (nmol/ml) & $0.73 \pm 0.18$ & $0.68 \pm 0.19$ & 0.482 \\
\hline Protein Carbonyl ( $\mu \mathrm{mo}$ I/L) & $26.63 \pm 18.06$ & $17.25 \pm 14.92$ & 0.091 \\
\hline +dfs & $3.91 \pm 3.39$ & $4.60 \pm 3.57$ & 0.672 \\
\hline +DMFS & $0.66 \pm 1.07$ & $1.16 \pm 1.68$ & 0.482 \\
\hline
\end{tabular}


There was no statistically significant relationship between age and SOD, FRAP, protein thiols, total sialic acid, TBARS and protein carbonyl levels in the CHD group (p>0.05) (Table 2).

The salivary buffering capacity and TBARS were significantly greater in the CHD groups, especially in the 7-12 years group ( $\mathrm{p} \leq 0.01 ; \mathrm{p}<0.05$ ) (Table 3 ).

There was no statistically significant difference between ACE inhibitors usage and SOD, FRAP, protein thiol, total sialic acid, TBARS, protein carbonyl, dfs and DMFS in the CHD group ( $p>0.05$ ) (Table 4).

The statistically significant difference was not found between cardiac status and SOD, FRAP, protein thiol, total sialic acid, TBARS, protein carbonyl, dfs and DMFS in the CHD group ( $p>0.05$ ) (Table 5).

There was statistically significant positive relationship between SOD and TBARS levels in the control group children $(r=0.323, p=0.042, p<0.05)$ (Table 6).

\section{Discussion}

The risk of caries is especially important for young children and those with systemic disease. The frequency of high car- ies in these patients is unacceptable. . Apositive correlation was found between the caries prevalence and age in this study.

Statistically significant differences were not found between df, dfs, DMF, and DMFs scoresaccording to the groups. The cardiac group received more interest in the efforts to prevent caries because they were being monitored by health proffesionals most of the time. Also, the parents tended to be attentive and care for their children's dental care. One of the factors that may lead to caries in CHD children has been found to be medication-induced xerostomia. Heart failure medication may lead to reduced salivary secretation, and therefore caries. Clinically, the children who experince heart diseases are given antibiotics more than the healthy ones, although no higher Streptococcus Mutans (MS) have been observed in children with heart disease. On the other hand, children between the ages 5 to 12 who had used antibiotics at an earlier age had higher MS levels (23).

Although long term medication need for CHD children is a common knowledge, the knowledge of how this regular use of medication affects the medically comprimised children's oral health is inadequate. Long term use of medications with low ph, high acidity, and fermentable sugars may create a

Table 5. Evaluation of SOD, FRAP, protein thiol, total sialic acid, TBARS, protein carbonyl, dfs ve DMFS according to cardiac status in the CHD group

\begin{tabular}{|c|c|c|c|c|}
\hline \multirow[b]{2}{*}{ CHD group } & & \multirow[b]{2}{*}{${ }^{+} p$} \\
\hline & $\begin{array}{c}\text { ASD } \\
\text { Mean } \pm S D\end{array}$ & $\begin{array}{c}\text { VSD } \\
\text { Mean } \pm S D\end{array}$ & $\begin{array}{c}\text { other } \\
\text { Mean } \pm S D\end{array}$ & \\
\hline SOD (U/ml) & $1.55 \pm 0.64$ & $1.47 \pm 0.63$ & $1.49 \pm 0.56$ & 0.961 \\
\hline FRAP $(\mu \mathrm{mol} / \mathrm{L})$ & $662.80 \pm 146.08$ & $614.03 \pm 155.53$ & $623.88 \pm 186.27$ & 0.849 \\
\hline Protein thiol ( $\mu \mathrm{mol} / \mathrm{L})$ & $51.51 \pm 24.38$ & $58.60 \pm 27.97$ & $57.37 \pm 26.60$ & 0.866 \\
\hline Total sialic acid (mg SA/dL) & $8.31 \pm 3.08$ & $7.82 \pm 2.72$ & $6.89 \pm 1.91$ & 0.300 \\
\hline TBARS (nmol/ml) & $0.68 \pm 0.10$ & $0.65 \pm 0.17$ & $0.72 \pm 0.21$ & 0.576 \\
\hline Protein Carbonyl ( $\mu \mathrm{mo} \mathrm{I/L)}$ & $28.71 \pm 18.34$ & $18.65 \pm 15.85$ & $17.43 \pm 15.28$ & 0.235 \\
\hline +dfs & $3.63 \pm 3.40$ & $4.37 \pm 4.24$ & $5.83 \pm 2.94$ & 0.131 \\
\hline +DMFS & $1.13 \pm 1.69$ & $1.50 \pm 1.69$ & $0.50 \pm 1.00$ & 0.377 \\
\hline
\end{tabular}

Table 6. Relationship between SOD-FARP and TBARS, protein carbonyl, protein thiol, total sialic acid in the groups

\begin{tabular}{|c|c|c|c|c|c|}
\hline & & \multicolumn{2}{|c|}{ SOD (U/ml) } & \multicolumn{2}{|c|}{$\operatorname{FRAP}(\mu \mathrm{mol} / \mathrm{L})$} \\
\hline & & $r$ & $p$ & $r$ & $p$ \\
\hline \multirow[t]{4}{*}{ CHD group } & TBARS (nmol/ml) & -0.151 & 0.339 & 0.286 & 0.086 \\
\hline & Protein carbonyl ( $\mu \mathrm{mol} / \mathrm{L}$ ) & 0.210 & 0.182 & 0.094 & 0.579 \\
\hline & Protein thiol ( $\mu \mathrm{mol} / \mathrm{L})$ & 0.218 & 0.217 & 0.073 & 0.682 \\
\hline & Total Sialic Acid (mg SA/dL) & -0.013 & 0.936 & -0.208 & 0.216 \\
\hline \multirow[t]{4}{*}{ Control group } & TBARS (nmol/ml) & 0.323 & $0.042 *$ & -0.202 & 0.223 \\
\hline & Protein Carbonyl ( $\mu \mathrm{mol} / \mathrm{L})$ & 0.066 & 0.733 & -0.222 & 0.257 \\
\hline & Protein thiol ( $\mu \mathrm{mol} / \mathrm{L})$ & 0.081 & 0.647 & -0.090 & 0.626 \\
\hline & Total Sialic Acid (mg SA/dL) & 0.120 & 0.486 & -0.306 & 0.078 \\
\hline
\end{tabular}

Pearson correlation analyses, ${ }^{*} \mathrm{p}<0.05$ 
direct oral health concern on thedental caries and/or erosive lesions apart from the concerns raised by salivary secretion $(3,24)$. In this study, the groups showed no statistically significant differences in terms of the mean salivary secretion rate.

The results of the studies in paediatric cardiology indicate some of the pharmaceutical preparations may cause caries and erosions, thus badly affecting oral health. The amount of saliva and its quality have significant importance for oral health as they might prevent dental carries and erosion. The salivary buffering capacity neutralizes acids in plague, dilute acids, transport the acid from the oral cavity, thus preventing a harmful $\mathrm{pH}$ change, and helps remineralization process by providing some minerals. Bicarbonate levels are important in maintaining the neutralization of acids and when salivary secretion is low the salivary buffering capacity also decreases (3). In this study the salivary buffering capacity and salivary $\mathrm{pH}$ were significantly less in the CHD than in the controls.

Many major drugs are not available in paediatric form. The most commonly used method is grinding the drug inside the syringe. Then by mixing the powder with tepid tap water in a plastic cup, it is made ready to administer. Pharmaceutical preparations with acidic $\mathrm{pH}$ like captopril could be a reason for low salivary $\mathrm{pH}$ and buffering capacity in children with CHD when used several times each day over long periods of time (25).

The first hypertension medicine taken orally to be released to the market was Captopril. It is an ACE inhibitor that prevents angiotensin I from turning into angiotensin II.Captopril includes thiol groups which allow specific binding to ACE and it suppresses the expression of the gene encoding ACE indirectly, therefore it is known to have specific inhibitory properties. Moreover, it has reaction ability to superoxide anion radicals, acting as a scavenger and to hydroxyl radicals, and it can improve the oxidative balance as well Ahmed et al. used captopril for the treatment of portal vein-ligated rats and reported significant elevations in glutathione (GSH) content and SOD activity (26).

Lipid peroxidation products MDA accumulates in the heart due to oxidative stress, which also leads to impaired cell function. On the other hand, antioxidant enzyme SOD helps to defend cells against oxidative stress. Sheng et al. measured the myocardial levels of the MDA content and SOD activities in order to prove that the cardiac hypertrophy model included oxidative stress. They've suggested that oxidative stress occurs during the development of cardiac hypertrophy, because the pressure overload is in the cardiac hypertrophy rat model, after aortic constriction, continious increase ocuured in the level of MDA contents in the hypertrophic myocardium at three, five, and 7 weeks. Meanwhile the SOD activities reduced slowly (27).

In this study, the TBARS and protein carbonyl were significantly higher in the CHD patients. This may be regarded as an indicator of oxidative stress due to heart disease. Salivary SOD activity was not statistically significant, even though a tendency towards increase was noticed.

SOD, FRAP, and protein thiols (i.e. enzymatic and non-enzymatic antioxidants), being no different between the groups, and it may depend on the use of the captopril and enalapril.

The results show that how oxidative stress and antioxidant systems in saliva of persons with caries affect each other is only partly understood. In this study, we also investigated levels of the sialic acids in whole saliva of the participants. Sialic acids on the terminal position in the mucins are believed to be important in antioxidant defense (28). The salivary total SA levels were correlated with the dental caries status, oral hygiene, and the gingival status in the children with CHD, but in only one study (29).

High levels of TBARS and protein carbonyl related to a higher oxidative stress present in saliva of children with CHD. Further investigations into the connection between these factors and development of oral diseases are required in cardiac patients. For this reason, researches in antioxidant and anti-inflammatory strategies may provide new treatments that reduce the damage caused by the imbalance in the oxidative system.

This research can be considered as a pilot study.The limitation of this study is the lack of the number of cases. In addition, the number of drug users and the degree of cardiological disease should be defined as subgroups. Evaluation of parameters should not only be limited to saliva and should provide more reliable results. More studies are needed to evaluate cardiac diseases and saliva composition. However, as far as we know, this is the first study in children to evaluate salivary oxidative stress parameters and dental caries. There have been many studies on dental caries and on periodontal diseases in subjects with cardiovascular disease. These studies have generally only investigated the $\mathrm{pH}$ and the flow rate. Studies about salivary composition of subjects with cardiovasccular diseases are limited. Paediatric cardiologists and paediatric dentists should work more closely for better dental care for cardiac patients. Children with cardiac diseases should be consulted to a paediatric dentist at an early age. Each child with a cardiac disesase should be able to receive an individual treatment plan to maintain oral health, based on risk assessment. The first aim of these programs should be to prevent caries with dietary counselling, oral hygiene, and fluoride applications if necessary. The challenges of the cardiac diseases and families with the cardiac patients's experience should not be underestimated and should be recognized.

\section{Conclusion}

The elevated TBARS and protein carbonyl levels in the patients with CHD were observed as an indicator of the free radical damage which may lead to oxidative stress.

Türkçe Öz: Konjenital kalp hastalığına sahip çocuklarda tükürük profili. Amaç: Kalp hastalıklarında düzenli ilaç kullanımı ile düşük tükürük pH'sı ve tamponlama kapasitesi ortaya çıkmaktadır. Bu nedenle kardiyak hastalarda ağız sağlığı desteklenmelidir ve düzenli takip şarttır. Bu çalışmanın amacı, konjenital kalp hastalığı olan çocuklarda tükürük oksidatif stres belirteçleri ile tükürük pH, tükürük tamponlama kapasitesi, tükürük akış hızı ve diş çürüğü arasındaki ilişkiyi değerlendirmektir. Yöntemler: Bu kesitsel çalışma 42 konjenital kalp hastası ve 42 sağlıklı çocuk ile yapılmıştır. Katılımcıların cinsiyet, yaş, genel sağlık ve kullandıkları ilaçları ile çürük skorları (dfs / DMFS) kaydedilmiş, uyarılmamış tükürük örnekleri toplanmıştır. Bu örnekler tükürük sekresyon miktarı, tükürük tamponlama kapasitesi, $\mathrm{pH}$, protein düzeyleri, süperoksit dismutaz (SOD), ferrik indirgeyici antioksidan güç (FRAP), tiyobarbitürik asit reaktif maddeler (TBARS), protein karbonil, protein tiyolleri ve toplam sialik asit açısından değerlendirilmiştir. Bulgular: Her iki grup da benzer oranlarda çürük olduğu saptanmıştır. Konjenital kalp hastalığına sahip çocuklarda tükürük pH'sı ve tamponlama kapasitesi 
kontrol grubuna göre anlamlı olarak daha az bulunmuştur. Konjenital kalp hastalığına sahip çocuklarda kontrol grubuna göre TBARS ve protein karbonil düzeyleri anlamlı olarak yüksek bulunmuştur. Ortalama tükürük sekresyon miktarı, protein düzeyleri, SOD, FRAP, protein tiyolleri ve toplam sialik asit ile ilgili anlamlı bir fark bulunmamıştır. Sonuç: Konjenital kalp hastalığına sahip çocuklarda yükselmiş TBARS ve protein karbonil düzeyleri, oksidatif strese yol açan serbest radikal hasarının bir göstergesi olarak gözlenmiştir. Anahtar Kelimeler: Tükürük kompozisyonu; antioksidant aktivite; çürük risk faktörleri; konjenital kalp hastalığı; çocuk dişhekimliği

Ethics Committee Approval: The study was approved by the Ethics Committee of the Istanbul University, Medical Faculty (No:2010/1109-378) and was carried out in agreement with the Declaration of Helsinki principles. The study was registered at ClinicalTrials.gov (NCT03457974).

Informed Consent: The informed consents were provided by the participants' parents.

\section{Peer-review: Externally peer-reviewed.}

Author contributions: MK, SB, MB and FS designed the study. MK, $\mathrm{MB}$ and $\mathrm{EU}$ participated in generating the data for the study. MK, $\mathrm{SB}$, $M B$ and $E U$ participated in gathering the data for the study. SB, EU, YG and FS participated in the analysis of the data. MK, SB and MB wrote the majority of the original draft of the paper. MK and MB participated in writing the paper. All authors approved the final version of this paper.

Conflict of Interest: The author had no conflict of interest to declare.

Financial Disclosure: This project was supported by the Research Fund of the Istanbul University. Project No: UDP-31219.

Acknowledgments: The authors thank Dr. Duygu Terzioglu for her assistance in the laboratory analysis of this study. Thanks to the families for their participation. We would also like to thank Selin Meral, Alexandre Rezende Vieira and Elaine Dizak for English grammer check.

\section{References}

1. Hoffman JIE, Kaplan S. The incidence of congenital heart disease. J Am Coll Cardiol 2002;39:1890-900. [CrossRef]

2. Cameron AC, Widmer RP. Handbook of Pediatric Dentistry 4th Ed.Mosby;. 2013, p.490-4.

3. Rosén L, Rydberg A, Sjöström I, Stecksén-Blicks C. Saliva profiles in children using heart failure medication: a pilot study. Eur Arch Paediatr Dent 2010;11:187-91. [CrossRef]

4. Koerdt S, Hartz J, Hollatz S, Frohwitter G, Kesting MR, Ewert P, et al. Dental prevention and disease awareness in children with congenital heart disease. Clin Oral Investig 2018;22(3):1487-93. [CrossRef]

5. Aizenbud D, Peri-Front $Y$, Nagler RM. Salivary analysis and antioxidants in cleft lip and palate children. Arch Oral Biol 2008;53:517-22. [CrossRef]

6. Foley JD, Sneed JD, Steinhubl SR, Kolasa J, Ebersole JL, Lin Y, et al. Oral fluids that detect cardiovascular disease biomarkers. Oral Surg Oral Med Oral Pathol Oral Radiol 2012;114:207-14. [CrossRef]

7. Dekker RL, Lennie TA, Moser DK, Miller CS, Ebersole JL, Chung $M L$, et al. Salivary Biomarkers, Oral Inflammation, and Functional Status in Patients With Heart Failure. Biol Res Nurs 2017;19:15361. [CrossRef]

8. Hamilton $\mathrm{C}$, Miller WH, Al-Benna S, Brosnan MJ, Drummond $\mathrm{RD}, \mathrm{McBride} M \mathrm{MW}$, et al. Strategies to reduce oxidative stress in cardiovascular disease. Clin Sci (Lond) 2004;106:219-34. [CrossRef]
9. Jain AK, Mehra NK, Swarnakar NK. Role of Antioxidants for the Treatment of Cardiovascular Diseases: Challenges and Opportunities. Curr Pharm Des 2015;21:4441-55. [CrossRef]

10. Tóthová L, Kamodyová N, Červenka T, Celec P. Salivary markers of oxidative stress in oral diseases. Front Cell Infect Microbiol 2015;20:-73. [CrossRef]

11. Tulunoglu Ö, Demirtas S, Tulunoglu I. Total antioxidant levels of saliva in children related to caries, age, and gender. Int J Paediatr Dent 2006;16:186-91. [CrossRef]

12. Ericsson $Y$. Clinical investigations of the salivary buffering action. Acta Odontol Scand 1959;17:131-65. [CrossRef]

13. Smith PK, Krohn RI, Hermanson GT, Mallia AK, Gartner $\mathrm{FH}$, Provenzano MD, et al. Measurement of protein using bicinchoninic acid. Anal Biochem 1985;150:76-85. [CrossRef]

14. Sun Y, Oberley LW, Li Y. A simple method for clinical assay of superoxide dismutase. Clin Chem 1988;34:497-500.

15. Benzie IFF, Strain JJ. Ferric reducing/antioxidant power assay: Direct measure of total antioxidant activity of biological fluids and modified version for simultaneous measurement of total antioxidant power and ascorbic acid concentration. Methods Enzymol 1999;299:15-27. [CrossRef]

16. Higueras V, Raya Á, Rodrigo J, Serra MÁ, Romá J, Romero FJ. Interferon decreases serum lipid peroxidation products of hepatitis C patients. Free Radic Biol Med 1994;16:131-3. [CrossRef]

17. Reznick AZ, Shehadeh N, Shafir Y, Nagler RM. Free radicals related effects and antioxidants in saliva and serum of adolescents with Type 1 diabetes mellitus. Arch Oral Biol 2006;51:640-8. [CrossRef]

18. Ellman GL. Tissue sulfhydryl groups. Arch Biochem Biophys 1959;82:70-7. [CrossRef]

19. Sedlak J, Lindsay RH. Estimation of total, protein-bound, and nonprotein sulfhydryl groups in tissue with Ellman's reagent. Anal Biochem 1968;25:192-205. [CrossRef]

20. Aminoff D. Methods for the quantitative estimation of $\mathrm{N}$-acetylneuraminic acid and their application to hydrolysates of sialomucoids. Biochem J 1961;81:384-92. [CrossRef]

21. Skoza L, Mohos S. Stable thiobarbituric acid chromophore with dimethyl sulphoxide. Application to sialic acid assay in analytical de-O-acetylation. Biochem J 1976;159:457-62. [CrossRef]

22. Tram TH, Brand Miller JC, McNeil Y, McVeagh P. Sialic acid content of infant saliva: Comparison of breast fed with formula fed infants. Arch Dis Child 1997;77:315-8. [CrossRef]

23. Dasanayake AP, Roseman JM, Caufield PW, Butts JT. Distribution and determinants of mutans streptococci among AfricanAmerican children and association with selected variables. Pediatr Dent 1995;17:192-8.

24. Grahn K, Wikström S, Nyman L, Rydberg A, Stecksén-Blicks C. Attitudes about dental care among parents whose children suffer from severe congenital heart disease: a case-control study. Int J Paediatr Dent 2006;16:231-8. [CrossRef]

25. Nunn JH, Ng SKF, Sharkey I, Coulthard M. The dental implications of chronic use of acidic medicines in medically compromised children. Pharm World Sci 2001;23:118-9. [CrossRef]

26. Ahmed AF, El-Maraghy NN, Abdel Ghaney RH, Elshazly SM. Therapeutic effect of captopril, pentoxifylline, and cordyceps sinensis in pre-hepatic portal hypertensive rats. Saudi J Gastroenterol 2012;18:182-7. [CrossRef]

27. Sheng R, Gu ZL, Xie ML. Epigallocatechin gallate, the major component of polyphenols in green tea, inhibits telomere attrition mediated cardiomyocyte apoptosis in cardiac hypertrophy. Int J Cardiol 2013;162:199-209. [CrossRef]

28. Tsuber V, Kadamov Y, Tarasenko L. Activation of antioxidant defenses in whole saliva by psychosocial stress is more manifested in young women than in young men. PLoS One 2014; 19;9(12):e115048. [CrossRef]

29. Hegde AM, Kavita R, Sushma KS, Suchetha S. Salivary sialic acid levels and dental health in children with congenital heart disease. J Clin Pediatr Dent 2012;36:293-6. [CrossRef] 